\title{
Erratum to: Paying the cost of skeptical theism
}

\author{
Jeff A. Snapper
}

Published online: 15 February 2011

(C) Springer Science+Business Media B.V. 2011

\section{Erratum to: Int J Philos Relig DOI 10.1007/s11153-010-9235-8}

The abstract and first paragraph of the online article are published incorrectly. They should read

Abstract In this paper I show that two arguments for the inconsistency of skeptical theism fail. After setting up the debate, I show why Mylan Engel's argument (Engel 2004) against skeptical theism does not succeed. I then strengthen the argument so that it both avoids my reply to Engel and parallels Jon Laraudogoitia's argument against skeptical theism (Laraudogoitia 2000). In the final section I provide three replies-one by an evidentialist theist, one by a closure-denying theist, and one by a necessitarian theist, and argue that the necessitarian's reply successfully rebuts the inconsistency charge. I conclude that skeptical theism which accepts God's necessary existence is immune to both kinds of arguments for its inconsistency.

First Paragraph

In this paper I show that two arguments for the inconsistency of skeptical theism (theism which is skeptical of inductive inferences from evil to atheism) fail. ${ }^{1}$ After setting

\footnotetext{
1 The locus classicus of the skeptical theism I address here is Wykstra (1984), but there are others. William Alston's skeptical theism makes the modest claim that "examining the interconnections of good and evil in the world by our natural powers cannot suffice to establish either [that there is gratuitous evil] or its negation" (Alston 1991, reprinted in Howard-Snyder 2004, p. 99). Although he does not advocate skeptical
}

The online version of the original article can be found under doi:10.1007/s11153-010-9235-8. 
up the debate, I show why Mylan Engel's argument against skeptical theism does not succeed. I then strengthen the argument so that it both avoids my reply to Engel and parallels Jon Laraudogoitia's argument against skeptical theism. In the final section I provide three replies - one by an evidentialist theist, one by a closuredenying theist, and one by a necessitarian theist — and argue that the necessitarian's reply successfully rebuts the inconsistency charge. I conclude that skeptical theism which accepts God's necessary existence is immune to both kinds of arguments for its inconsistency.

\section{References}

Alston, W. (1991). The inductive argument from evil and the human cognitive condition. Philosophical Perspectives, 5, 29-67.

Howard-Snyder, D. (Ed.). (2004). The evidential argument from evil. Bloomington: Indiana University Press.

Van Inwagen, P. (2006). The problem of evil. Oxford: OUP.

Wykstra, S. J. (1984). The Humean obstacle to evidential arguments from suffering: On avoiding the evils of appearance. International Journal of the Philosophy of Religion, 16, 73-93.

\section{Footnote 1 continued}

theism per se, Peter Van Inwagen says things akin to it. In particular, he claims to tells a story S such that an audience of ideal neutral agnostics would, if they heard it, agree that (i) S entails that God exists and huge amounts of animal suffering occurred, (ii) for all they know S is true, (iii) no particular probability assignment to $\mathrm{S}$ is more epistemically defensible than any other. Further, that ideal audience would agree that given (i)-(iii), any argument for God's nonexistence from evil cannot move ideal neutral agnostics to assign its conclusion a higher probability than they assigned it prior to considering the argument; consequently any such argument is not a success (Van Inwagen 2006, Chap. 7, esp. 114). 